\title{
The Rise of the Brokered State: Situating Administrative Expansion in Chosn Korea
}

\section{DOI:}

10.1353/seo.2019.0004

\section{Document Version}

Accepted author manuscript

Link to publication record in Manchester Research Explorer

\section{Citation for published version (APA):}

Lee, J. S. (2019). The Rise of the Brokered State: Situating Administrative Expansion in Chosn Korea. Seoul Journal of Korean Studies, 32(1), 81-108. https://doi.org/10.1353/seo.2019.0004

\section{Published in:}

Seoul Journal of Korean Studies

\section{Citing this paper}

Please note that where the full-text provided on Manchester Research Explorer is the Author Accepted Manuscript or Proof version this may differ from the final Published version. If citing, it is advised that you check and use the publisher's definitive version.

\section{General rights}

Copyright and moral rights for the publications made accessible in the Research Explorer are retained by the authors and/or other copyright owners and it is a condition of accessing publications that users recognise and abide by the legal requirements associated with these rights.

\section{Takedown policy}

If you believe that this document breaches copyright please refer to the University of Manchester's Takedown Procedures [http://man.ac.uk/04Y6Bo] or contact uml.scholarlycommunications@manchester.ac.uk providing relevant details, so we can investigate your claim.

\section{OPEN ACCESS}




\title{
The Rise of the Brokered State: Situating Administrative Expansion in Chosŏn Korea* $^{*}$
}

\author{
John S. Lee
}

Between 1500 and $1800 \mathrm{CE}$, patterns of governance on the Korean peninsula shifted toward a dynamic that I term the "rise of the brokered state." While central political authority increasingly became entrenched in a small number of elite families residing in the capital region, the reach of the Chosŏn state continued to grow through local institutions such as clerks and military garrisons. Likewise, avenues of interaction between Seoul and the provinces broadened thanks to the social and organizational consolidation of local elites. Over time, the government was able to utilize a widening assemblage of bureaucratic administration and local cooperation to expand state management of resources such as grain and timber. Previous scholarship has often situated Chosŏn center-local dynamics within vectors of conflict, stagnation, or progress. My analysis reframes Chosŏn administrative expansion as an interactive process through which a wide array of local yangban, clerks, military officials, and monks became key intermediaries between the central government and the provinces, in turn forming the infrastructural contours of the Chosŏn state itself.

Keywords: Chosŏn, brokerage, center-local dynamics, comparative state formation, environmental history.

\section{Introduction}

It can be agreed that the Chosŏn dynasty (1392-1910) was remarkable for its longevity.

Assessment of the dynasty's lifespan, however, runs into a morass of historiographical

contention. Japanese colonial-era scholars such as Fukuda Tokuzō depicted the Chosŏn era as one of socio-economic stagnation that left Korea underdeveloped and unprepared for the

John S. Lee (john.lee-5@ manchester.ac.uk) is Presidential Fellow in Environmental History in the Department of History, University of Manchester.

\footnotetext{
* The research and writing process for this article was aided by generous support from the Academy of Korean Studies (AKS-2015-C15) and a matching grant from the School of Languages and Cultures at the University of Hong Kong. I also thank the two anonymous reviewers for their detailed and incisive comments.
} 
modern world. ${ }^{1}$ In the 1960 s and 1970 s, the South Korean internal development school of Kim Yongsŏp unearthed an array of changing social dynamics in late Chosŏn society that highlighted social upheaval, progress, and "sprouts of capitalism.", In North America, James Palais characterized the Chosŏn order as an "aristocratic-bureaucratic balance," that is, a ruling elite marked by hereditary ascription but additionally defined by service in the central bureaucracy. By limiting the entrance of political newcomers and checking royal power, this aristo-bureaucratic hybrid, Palais argues, maintained Chosŏn's “remarkable stability" without the application of major structural reforms. ${ }^{3}$

While these aforementioned arguments may differ wildly in their conclusions, they share a commitment to static archetypes that implicate modalities of progress, stagnation, or modernization in Korean history. Rather than inserting Korea into teleological constructs or predetermined theories, this article situates the Chosŏn era in the longue durée dynamics of historical change on the Korean peninsula itself, within the long-term processes of centralization, administrative expansion, and local transformations.

In the previous article, Javier Cha explains the formation of a centralized aristocracy in the Koryŏ dynasty (918-1392). The early Chosŏn state was built upon the patrimonial structures and centripetal forces described by Cha. Aristocratic coalitions in Seoul, bound by conjugal ties and shared participation in civil examinations and the bureaucracy, accelerated ongoing patterns of centralization on the Korean peninsula. Fifteenth-century reformers established new administrative subdivisions, bestowed provincial governors with higher status and far-ranging powers, and revamped the land system in favor of greater access for

\footnotetext{
${ }^{1}$ Owen Miller, "The idea of stagnation in Korean historiography: from Fukuda Tokuzō to the New Right," Korean Histories 2, no. 1 (2010): 4-5.

${ }^{2}$ For an overview of internal development historiography, see Yun Haedong, Kŭndae yŏksahak ŭi hwanghon [The twilight of modern historiography] (Seoul: Ch'aek kwa hamkke, 2010), 36-67.

${ }^{3}$ James Palais, "Confucianism and the Aristocratic/Bureaucratic Balance in Korea," Harvard Journal of Asiatic Studies 44, no. 2 (1984), 427-468.
} 
members of the central bureaucracy. Simultaneously, Chosŏn bureaucrats embarked on an ambitious program of political and cultural reform, targeting everything from the role of the king and officials to the content of national customs (kuksok 國俗) and the position of women.

The rise of this particular blend of bureaucratic and cultural order, however, required a departure from previous trends in Korean history. The process of administrative expansion eventually produced a vast array of brokers — intermediaries who could fulfill the logistical demands of state. Policies necessitated implementation; ideas needed articulation; resources required identification, extraction, and distribution. From the sixteenth century onward, the infrastructural capacities of the Chosŏn state flowed through a wide range of local elites, middlemen, administrators, and soldiers who managed and intermediated increasingly complex links between Seoul and the provinces.

I refer to this post-1500 trend as the rise of the brokered state. By "state," I mean not only the capital-based government (the court, the central bureaucracy, and the capital-based military) but also the wider administrative apparatus represented by magistrates, clerks, and military officials in the countryside. Together, the central government and local administrators fit Max Weber's definition of the state as "that human community which (successfully) lays claim to the monopoly of legitimate physical violence within a certain territory." Moreover, the Chosŏn bureaucracy served as a mechanism for what Pierre Bourdieu refers to as "the symbolic violence over a definite territory." By instilling the need for "proper" rituals and "correct" gender roles, establishing "orthodox" interpretations of scholarship, and demarcating jurisdictional authority over key resources and their distribution, the Chosŏn state realized itself not just through the king and his ministers but also in the

\footnotetext{
${ }^{4}$ Max Weber, "The Profession and Vocation of Politics," in Weber: Political Writings, ed. Peter Lassman, trans. Ronald Speirs (Cambridge, UK: Cambridge University Press, 2018), 310-311.

${ }^{5}$ Pierre Bourdieu, Loic J. D. Wacquant, and Samar Farage, "Rethinking the State: Genesis and Structure of the Bureaucratic Field," Sociological Theory 12 (1994): 3.
} 
social and mental structures, intellectual pursuits, and broader aspirations of the yangban elite that multiplied in the provinces over the course of the dynasty.

I use the term "brokered state" to further distinguish the mid-to-late Chosŏn era from the patrimonial centralization of Korea's medieval period. Historical sociologist Charles Tilly used the term "patrimonialism" to define the tribute and feudal levy-based regimes that predominated in Europe until the fifteenth century. Tilly then applied the term "brokerage" to describe the subsequent period between "roughly 1400 to 1700 in important parts of Europe" when "rulers relied heavily on formally independent capitalists for loans, for management of revenue-producing enterprises, and for installation and collection of taxes.” The transition from patrimonial to brokered states was tantamount to European state formation- a process, according to Tilly, made possible by the changing "stakes of war." The medieval pattern of patrimonial extraction transitioned to territorialized brokerage as "closely administered territories became assets worth fighting for, since only such a territory provided the revenues to sustain armed force.",6

The Chosŏn context was somewhat different from cases described in classic historical-sociological literature in which western Europe, China, and Japan are the primary referents. Chosŏn had no feudal legacy. Unlike China and the Japanese archipelago, local warlordism was not an issue on the Korean peninsula after $1000 \mathrm{CE}$. While merchants and financiers became the primary brokers of state capacity in parts of western Europe, Chosŏn administrative expansion relied far more on the activities of lower-level clerks, military officials, and most importantly, official and nonofficial elites from the yangban stratum. ${ }^{7}$

\footnotetext{
${ }^{6}$ Charles Tilly, Coercion, Capital, and European States, AD 990-1990 (Oxford, UK; New York, NY: Basil Blackwell, 1990), 29.

${ }^{7}$ The yangban, literally meaning "two orders," were the elite stratum of Chosŏn society and politics, their proportion of the population being in the range of ten percent during the late Chosón period. Yangban, nominally, were all state examination passers, upper bureaucrats, and their kin and descendants, as well as country families who engaged in Confucian practices and education and could claim some sort of yangban descent. From the seventeenth century onward, certain yangban lineages would dominate important positions in
} 
State formation on the Korean peninsula between 1400 and 1800 was not the by-product of wartime finance or the challenges of local warlords. Rather, the Chosŏn state can be seen as a broadening assemblage of center-local interactions that developed gradually in response to infrastructural and political limits apparent from $1500 \mathrm{CE}$ onward.

With such historical differences in mind, the vocabularies of patrimonialism and brokerage remain useful. Karen Barkey reinterpreted Tilly's concepts in the context of the early modern Ottoman Empire to produce an exemplary study of how the Ottoman state incorporated bandits and other potentially uncooperative elements into the bureaucracy. ${ }^{8}$ Scholars of late imperial China, likewise, have meticulously detailed how imperial officials and local elites collaborated to broker state interests, developing what Prasenjit Duara calls a “cultural nexus of power" through which the imperial state could use various channelstemples, market networks, kinship groups, patron-client relationships - to reach into local communities. $^{9}$

Amidst the unreliable infrastructure and incomplete information that bedeviled preindustrial Eurasia, middlemen and intermediaries were essential tools of governance. Research on societies as disparate as ancient Egypt, the Roman Empire, and early modern France has highlighted the critical role played by local elites, tribal chieftains, tax farmers, and military garrisons in cementing central rule and facilitating the wider dissemination of goods and information. ${ }^{10}$ The vast array of intermediaries between the central and the local

central politics, while the majority of their status-group compatriots lived in the provinces. There, through powerful organizations and state-sanctioned privileges such as exemption from military service, they would dominate local social and economic life through the end of the dynasty.

${ }^{8}$ Karen Barkey, Bandits and Bureaucrats: The Ottoman Road to State Centralization (Ithaca, NY: Cornell University Press, 1994).

${ }^{9}$ Prasenjit Duara, Culture, Power, and the State: Rural North China, 1900-1942 (Stanford: Stanford University Press, 1988), 15-40.

${ }^{10}$ An illustrative recent study is Fiscal Regimes and the Political Economy of Premodern States, Andrew Monson and Walter Scheidel, eds. (Cambridge, UK: Cambridge University Press, 2015). 
formed the basis for a "state infrastructure," to use Philip Gorski's term, across early modern Eurasia, akin to "a communications network through which information flows between the central and the local or as a generator that feeds additional power to the state."11

South Korean historiography likewise has highlighted the rise of local and regional elites, particularly elements of the so-called sarim faction in the sixteenth century, as a key turning point away from the centralizing tendencies of the dynasty's founding elites. ${ }^{12}$ Economic historians of Korea have put forth detailed studies of the middlemen brokers such as the merchants who facilitated the expansion of the late Chosŏn economy. ${ }^{13}$ However, such studies have been largely descriptive: at most, they highlight the broker's role in the functioning of a larger political or fiscal system. I argue that the broker in the Chosŏn era was not simply a cog in a web of state institutions - he constituted the very matter of the web that was the Chosŏn state. Local elites disseminated, articulated, and practiced the dominant cultural ethos, notably Confucianism, and rendered them synonymous with the Chosŏn cultural order and the state's very legitimacy. Clerks, military officials, and tribute merchants distributed the resources that underpinned the state's revenue and security. The array of brokers who arose in the Chosŏn dynasty after the mid-sixteenth century distinguish the era and inscribe it in a longue durée pattern between the medieval patrimonialism described by Javier Cha and the post-1860 reformist administrations laid out by Holly Stephens.

\footnotetext{
${ }^{11}$ Philip S. Gorski, The Disciplinary Revolution: Calvinism and the Rise of the State in Early Modern Europe (Chicago; London: The University of Chicago Press, 2003), 166.

${ }^{12}$ Chŏng Tuhŭi, Chosŏn sidae ŭi taegan yŏn'gu [A study of the Censorate in the Chosŏn era] (Seoul: Ilchogak, 1994); Yi Pyŏnghyu, Chosŏn chŏn'gi Kiho sarimp'a yŏn'gu [A study of the Kiho Sarim faction in the early Chosŏn era] (Seoul: Ilchogak, 1984); Yi Sugŏn, Yŏngnam sarimp’a ŭi hyŏngsŏng kwa chŏngae [The formation and development of the Yŏngnam sarim faction] (Seoul: Ilchogak, 1995); Yi T'aejin, Han'guk sahoesa yŏn'gu [Studies in the social history of Korea] (Seoul: Chisik san'ŏpsa), 1986; Michael Shin, ed., trans., Everyday Life in Joseon Korea: Economy and Society (Leiden; Boston: Brill, 2014), 12-13.

${ }^{13}$ Kang Man'gil. Chosŏn sidae sanggongŏpsa yŏn'gu [A history of mercantile activity in the Chosŏn era] (Seoul: Han'gilsa), 1984; Ko Tonghwan, Chosŏn hugi Sŏul sanŏp paltalsa yŏn'gu [The development of commerce in late Chosŏn Seoul] (Seoul: Chisik sanŏpsa, 2002). For an English-language work, see Owen Miller, "The Silk Merchants of the Myŏnjujŏn: Guild and Government in Late Chosŏn Korea” (Ph.D. dissertation, School of Oriental and African Studies, University of London, 2007).
} 
What Chosŏn experienced between the early sixteenth and nineteenth centuries was not decentralization. The state did not "lose control." Rather, brokered interactions between center and local changed and reshaped the nature of the state. The mechanisms of developing and imposing political, social, and economic norms required the involvement of various elements that had not been nearly as significant or robust before the sixteenth century. The brokered state gradually arose after the turmoil of Yŏnsan'gun's reign (1494-1506) and peaked around 1800 after a century of increasing stability, population growth, and cultural and economic efflorescence, an era that built much of the popular imagination of what constitutes "traditional Korea." Culturally and ideologically, the Chosŏn era was when Confucian beliefs and practices gradually permeated the Korean peninsula. At the institutional level, brokered administration became the Chosŏn state's modus operandi, its mechanism for expansion and its basis for enduring stability.

Both South Korean and international research on Chosŏn Korea in the past three decades has produced a rich corpus of local histories and empirical institutional studies. These, along with my own primary research on Chosŏn-era forest management, will serve as the basis for the following argument. The rise of the brokered state between the early sixteenth and nineteenth centuries can be observed in four salient trends: one, the rise of local elites as key cultural and economic brokers in the sixteenth century; two, the growing role of local status-group, academic, and kinship organizations; three, the expanding functions of clerks and local military garrisons; and four, the increasing role that local brokers played in managing resources meant for state use (kugyong 國用) after 1600. The rise of local elites in the sixteenth century engendered a symbiotic relationship between themselves and the government. Local elites required state sanction to maintain their status and privileges; the state required local elite assistance to rule the country. After the devastating Imjin War (1592-1598) and Manchu incursions of 1627 and 1636, the government utilized clerks, 
military officials, and similar local bureaucratic organs to reassert control over a devastated countryside. Thus, the brokered state was the effect of a two-tiered process beginning with the mounting prominence of elites in the mid-sixteenth century and intensifying after 1600 as a widening array of military officials, clerks, and other lower-level officials brokered the links between capital and countryside.

\section{Local Elites and the Sixteenth-Century Shift}

In his magnum opus, Confucian Statecraft and Korean Institutions: Yu Hyǒngwǒn and the late Chosǒn Dynasty, James Palais described sixteenth-century Korea as a time of political and social "disintegration," an era when the high-minded reformism that had launched the dynasty degenerated into "maladministration [and] internecine bureaucratic factionalism," and Chosǒn society became beset with what Palais calls "negative trends" — "the concentration of wealth, the evasion of responsibility, and the deterioration of national defense." ${ }^{14}$ Only the devastating Hideyoshi invasions at the end of the century, attests Palais, gave the Chosǒn dynasty a chance to rebuild.

Negative perceptions of the sixteenth century in Korean historiography dwell on the failed promises of early Chosŏn statecraft. The reformist dreams of fifteenth-century scholars, in Palais' view, fell into the quagmire of elite self-interest and irresponsibility. Some South Korean scholars such as Kim Sŏngu have similarly portrayed the sixteenth century as a "dismal period in Korean history" when political turmoil, administrative corruption, and the end of government support for irrigation facilities led to economic decline in areas such as Sŏnsan County in Kyŏngsang Province. ${ }^{15}$

\footnotetext{
${ }^{14}$ James B. Palais, Confucian Statecraft and Korean Institutions: Yu Hyǒngwǒn and the Late Chosǒn Dynasty (Seattle: University of Washington Press), 1004.

${ }^{15}$ Sung Woo Kim [Kim Sŏngu], "Decline of a Confucian Mecca: Development of Rice Farming and Regional Development in Chosŏn Korea," Journal of Korean Studies 15, no. 1 (2010): 1-40.
} 
Other historians, however, have noted that the sixteenth century also coincided with periods of economic growth and the expansion of a key group: local elites. Kim Sŏngu himself notes that, even while Sŏnsan declined in the sixteenth century, upland areas of Kyŏngsang province such as Yean grew in wealth and stature. ${ }^{16}$ The spread of rice transplantation and small-scale irrigation techniques helped support an increasingly confident rural elite in parts of southeastern Korea. Yean, for instance, grew into a prominent town, home to Neo-Confucian scholar Yi Hwang (1501-1570) and an assertive scholarly culture that regularly saw local literati insert themselves in central politics through the dissemination of joint memorials. ${ }^{17}$

The localization thesis, that local elite consolidation from the mid-sixteenth century onward had profound implications for the Chosŏn dynasty, is part of Martina Deuchler's longue durée study of the Chosŏn ascriptive elite. ${ }^{18}$ Anchored in kinship-centered descent groups and further defined by shared participation in ritual and scholarly affairs, the Chosŏn elite, the sajok, were able to maintain their socio-political dominance until the end of the Chosŏn dynasty. Their dominance of central politics can be traced to the fifteenth century, and in the case of some illustrious families further back to even the Koryŏ and Silla eras. Elite ascendancy in the countryside, however, required a "localizing" transition from the fifteenth through the sixteenth centuries, when established kinship groups reclaimed land and brought tax-burdened small cultivators under their protection (often as bonded slaves). "By 1600," writes Deuchler, the sajok "controlled the countryside."19

\footnotetext{
${ }^{16}$ Ibid., 34.

${ }^{17}$ Hwisang Cho, "The Epistolary Brush: Letter Writing and Power in Chosŏn Korea," The Journal of Asian Studies 75, no. 4 (November) 2016: 1070-1075.

${ }^{18}$ Martina Deuchler, Under the Ancestors' Eyes: Kinship, Status, and Locality in Premodern Korea (Cambridge, MA: Harvard University Asian Center, 2015), 96-102.

${ }^{19}$ Ibid., 399.
} 
By the mid-seventeenth century, local elites had emerged as the primary intermediary transmitting Confucian culture between state and locality. Many understood themselves as “local grand officers" (hyang taebu 鄉大夫) tasked with the role of "rectifying the local mores" and protecting the community's moral reputation. ${ }^{20}$ Hwisang Cho argues that local elites further consolidated their dominance by using certain textual practices, notably epistolary interactions and the penning of joint memorials, to simultaneously access a sense of participation in central politics and solidify a network of Confucian elites within a given locality. ${ }^{21}$ Such were the benefits of brokerage: in linking center and local to serve the state's interests, local elites also served their own.

Accordingly, local elites also became key engines of economic growth, particularly through the method with the best marginal returns in the early Chosŏn era: land reclamation. Yi Sugŏn and Kim Kŏnt'ae have touted the sixteenth century as an era when local elites furthered their role in agricultural development, especially in the southern provinces of Chŏlla, Kyŏngsang, and Ch'ungch'ŏng. According to their line of argument, local elites emerged in areas where land and labor were available to claim and where reliable water supplies facilitated the spread of wet-rice cultivation. ${ }^{22}$ The process was indeed, in Martina Deuchler's words, a "land grab.",23

Government policy further incentivized the agricultural expansion that underlay the dominance of the yangban stratum in the provinces. Reclamation rights were encoded in the Great Code of Administration (Ky̆̌ngguk taejŏn): "If one has laid out and occupied a field

\footnotetext{
${ }^{20}$ Ibid., 208, 220.

${ }^{21}$ Hwisang Cho, "The Epistolary Brush," 1069-1070, 1074-1075.

${ }^{22}$ Kim Kŏnt'ae, Chosŏn sidae yangban'ga ŭi nongŏp kyŏngyŏng [Yangban landlordism during the Chosŏn dynasty] (Seoul: Yŏksa pip'yŏngsa, 2004); Yi Sugŏn, Yŏngnam hakp'a ŭi hyŏngsŏng kwa chŏn'gae [The formation and development of the Yongnam faction] (Seoul: Ilchogak, 1995); Martina Deuchler, Under the Ancestors' Eyes, 96-102.

${ }^{23}$ Deuchler, Under the Ancestors' Eyes, 96.
} 
for three years, the occupier then possesses the land." 24 John Richards characterizes such property laws - "the rights to occupy, alienate, mortgage, and bequeath lands so owned"- as "common to settled societies in [early modern] Eurasia." 25 State sanction and the solidification of usage rights drove the clearing and cultivating of the frontier throughout the pre-industrial world, and Korea was no different in following this pattern.

It is important to note that "state sanction" was key. Local elites required close cooperation with the state to acknowledge property rights and acquire resources; the state, in turn, required cooperation to govern the countryside and extract taxes, tribute, and corvée labor. Kim Sŏngu has argued that reductions in government support for dikes and irrigation caused agricultural productivity to fall in some areas in the early sixteenth century. ${ }^{26}$ While central support for local activities may have diminished, local elites were often able to fill the vacuum, in turn enriching their own patrimonies. Elite "localization" in this period, writes Deuchler, "meant the appropriation of a particular locale as economic basis for maintaining, through continued examination success and/or marital ties, relations to the center.",27

In the next two sections, I use two case studies to peer further into the rise of local elites in the sixteenth century. In the first, I examine how one prominent yangban in Chŏlla province collaborated with state officials to acquire construction material for himself and his kin. In the second case, I shed light on another yangban from Kyŏngsang province who utilized his position to assist the state's tribute collection system while also enriching himself. Together, the cases reflect the symbiotic relationship between Chosŏn local elites and the wider state. The state could not function without local elites acting as cultural and economic

\footnotetext{
${ }^{24}$ Kyŏngguk taejŏn [The Great Code of Administration] (Seoul: Yŏngang ch'ulp'ansa, 2001), 2.12a.

${ }^{25}$ John F. Richards, The Unending Frontier: An Environmental History of the Early Modern World (Berkeley: University of California Press, 2003), 5.

${ }^{26}$ Sung Woo Kim, "Decline of a Confucian Mecca."

${ }^{27}$ Deuchler, Under the Ancestors' Eyes, 102.
} 
brokers; likewise, local elites depended on state recognition of their privileges in order to protect their interests.

\section{The Local Limits of the Chosŏn State: Miam Yu Hŭich'un and State Forests in the Sixteenth Century}

The intersection of state, local elites, and forests provides an instructive starting point for understanding the rise of the brokered state. In its incipient decades, the Chosorn government recognized the fundamental importance of the wood supply and cordoned off forests around the capital city of Seoul and along the coasts as Restricted Forests (kŭmsan 禁山) for “state use.” In various ways, forest resources helped assuage concerns that were pressing the new dynasty. Maritime raiders could be defeated with more and better warships. The monarchy could legitimize its authority by building up Seoul, using forests to build new palaces and government offices. The state could actively reform national customs, starting with the very way the population buried their dead. In each case, from warships to buildings to coffins, wood resources were vital.

At the same time, the state could not simply gather timber at will. Forest resources were sought and used by all people, for fuel wood and construction, as swidden and reclaimable land, and as hunting and grazing grounds. From the beginning of the dynasty, Chosŏn government officials were aware of the contested materiality of forests and accordingly worried over timber scarcity, over forests being exhausted by the very people they governed. Their solution was to create a new administrative category, the Restricted Forest and protected pine groves (song chi ch'ó 松之處), to protect the timber supply.

The central government initially put Restricted Forests under the authority of magistrates, military officials, and locally recruited wardens (sanjik山直). By the sixteenth 
century however, local elites without formal office were handling wood distribution for the benefit of both themselves and, nominally, the state.

An instructive case is that of Yu Hŭich'un (1513-1577), penname Miam, an official who, when not serving in the Chosŏn court, stayed at his family residences in Haenam and Tamyang in southern Chŏlla province. There, like numerous yangban of his generation who ran through the gauntlet of purges and political struggles, Miam benefited from his dual role as rusticated elite and former bureaucrat. He had once held numerous important posts, including that of Chŏlla provincial governor (Kwanch'alsa 觀察使), and he accordingly still had considerable sway in the community.

Southern Chŏlla was also a center of state forestry. Miam's birthplace, Haenam county, was home to six Restricted Forest sites. Between 1569 and 1577, Miam built four houses in the area: two in Haenam and Ch'angp'yŏng, one for his concubine in Haenam, and another for his sister in nearby Kangjin. Each of the houses required lumber partly or fully acquired from the Restricted Forests.

When Miam began constructing his house in Haenam in southern Chŏlla province, he procured the lumber by soliciting military officials over meals and drinks. When Miam inquired about lumber with a military official named Yi Sǒnwǒn, the man answered most enthusiastically, "Would I not assist you without hesitation, with all my heart?",28 Miam described another successful lumber solicitation as follows:

Around sunset, the honorable Navy Commander So Hǔp came up from Ǒran. He presented me some meat and cakes, and we poured each other drinks. Pak Hae and Paek Kwanghun also joined in. I brought up [the topic of] lumber for construction, and the honorable So Hǔp agreed [to assist]. ${ }^{29}$

\footnotetext{
${ }^{28}$ Miam ilgi, 1567/12/17.

${ }^{29}$ Miam ilgi,1569/02/11.
} 
Military officials, the very people charged with guarding Restricted Forests, were instead procuring access for a prominent local elite.

Officials even allocated state resources to assist in the distribution of Miam's lumber. Later, Miam sent his son-in-law to a Restricted Forest on Wando island off the southwest coast to retrieve necessary lumber. ${ }^{30}$ In his son-in-law's words, the local military official there welcomed him warmly and then "sent off [the lumber] on three ships, in an amount sufficient for building bigger than a twenty- $k$ 'an house."31 Once the lumber from Wando reached the mainland docks, a guard was required to protect more than 300 pieces of "floor, beam, and pole wood" as they lay naked on the banks. The guard was procured, not through impersonal economic transaction, but through a local magistrate who appointed someone to watch over Miam's lumber. ${ }^{32}$ Similarly, when Miam was building his sister's house, he ran into difficulties transporting the necessary lumber to the construction site. He solved the problem by paying barley to a prominent official named Ch'oe Kyŏngjang (1529-1601), who then ordered grain-loan shippers (hwanja) to transport the lumber on Miam's behalf.

Once construction begins, Miam's various connections came together to fuel his project. Miam not only solicited military officers, but also relatives, friends, monks, civil officials, and local organizations for construction resources and supplies. Associates allowed Miam to access wood from their forests. ${ }^{33}$ In-laws and a local yangban association sent workers and slaves. More lumber and tiles poured in from officials and monks. When Miam needed the services of a carpenter (mokchang 木匠) during the construction of his

\footnotetext{
${ }^{30}$ While most of the state forests in the southwestern islands were established after the Imjin War, the island of Wando would be the site of major forestry operations for the entirety of the Chosŏn dynasty and even into the colonial era.

${ }^{31}$ Miam ilgi, 1569/05/04. "K'an" is the measure for the space between two poles of a Chosǒn-era house.

${ }^{32}$ Miam ilgi, 1569/06/19.

${ }^{33}$ Miam ilgi, 1571/02/13.
} 
concubine's house, his friend Kim Sǒngwǒn sent him a slave skilled in woodwork. In return, Miam gave the slave an ink stick to send back to his master.

Such access to state forests and open collusion with state officials is eye-opening. I argue that Miam's privileged access to Restricted Forest lumber was a symptom of the broader tension between fifteenth-century policies and sixteenth-century realities. The forestry system launched at the beginning of the dynasty, driven so strongly by the state's preferences for pine timber, had to yield to changing social and economic dynamics on the ground. In the process, sylvan space acquired different properties. From the state's timber-

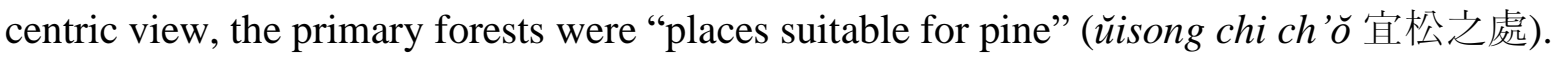
Fire could render a forest into hazard or taxable plot. For the growing stratum of local elites, forests could serve as sites for increasing wealth and solidifying their position as brokers between the state and the broader populace.

Simply put, Miam's situation provides a stark glimpse into the political economy of sixteenth-century Korea, into an array of personal networks lying outside the bounds of legally sanctioned, impersonal economic transactions. Such exchanges, for Chosŏn elites such as Miam, provided access to resources technically accessible only through the mechanisms of the Chosŏn bureaucracy. Miam and similar local elites exposed a problem that would bedevil Chosŏn state forestry for the rest of the dynasty. Namely, state forestry's sustainability was premised on protecting government forests from the general populace. The original system built in the fifteenth-century had not accounted for a rising stratum of extragovernmental elites blessed with both local power bases and government connections. The growing ranks of localized elites, of whom Miam is representative, grew into the critical link between the central government that needed resources and the localities that could provide them. 


\section{Local Elites as Resource Brokers: The Case of Mukchae Yi Mun'gŏn}

Another fitting example of local elite brokerage is that of Miam's contemporary Yi Mun'gŏn (1494-1567), penname Mukchae. Mukchae was a former court official who, after being purged from office in Seoul in 1546, moved to his wife's hometown of Koesan and then to his own hometown of Sŏngju in northern Kyŏngsang province. He quickly settled in as a powerful intermediary between the local magistrates and general populace. Mukchae assisted government officials in various aspects of tax and tribute collection; at the same time, he utilized government resources and laborers for his own interests. One curious role that he acquired was that of intermediary fur broker. The story of why he wanted the position - and why it was important — further elucidates how local elites facilitated new patterns of resource allocation in sixteenth-century Korea. ${ }^{34}$

To understand why the position of fur broker was sought after and why it was even available, one must review the ongoing shift in state-sponsored hunting from the fifteenth to the sixteenth centuries. Since the beginning of the dynasty, state game reserves (kangmujang 講武場) had provided furs, feathers, and specialty meats such as deer and pheasant for royal consumption and sacrificial offerings. State game reserves were also considered prime sources of military training, particularly for cavalry. ${ }^{35}$ Thousands, even tens of thousands, of soldiers at a time would be involved in massive hunts that helped improve horsemanship,

\footnotetext{
${ }^{34}$ Mukchae's diary, the Mukchae ilgi recorded from 1535 to Mukchae's death in 1567 , is one of the oldest extant private diaries from the Chosŏn era. All references to the diary will be cited in the following format. Book number : volume number, page number (Seoul: Kuksa p'yŏnch'an wiwŏnhoe, 1998).

${ }^{35}$ Large-scale royal hunts in early modern Eurasia, as Thomas Allsen argues, carried heavy political meaning. They displayed a ruler's ability to command manpower and animals alike to people throughout the countryside and to subjects high and low. Royal hunts, as spectacle and mass project, affirmed the government's ability to govern. Thomas T. Allsen, The Royal Hunt in Eurasian History (Philadelphia: University of Pennsylvania Press, 2006), $8-10$.
} 
archery, and unit cohesion. ${ }^{36}$ Dynastic founder T'aejo decreed major hunts to be held at the end of every season around Seoul and at the end of every spring and autumn in the provinces, thus keeping the military sharp and the court well-supplied. ${ }^{37}$

However, by the late fifteenth century, military reorganization and environmental changes were transforming the function of game reserves in Kyŏnggi, northern Ch’ungch'ŏng, and western Kangwŏn provinces. During Sŏngjong’s reign, court officials regularly debated which reserves to open or close. In 1481 for instance, the Board of Military Affairs (Pyŏngjo 兵曹) recommended the opening of all reserves to woodcutting and private hunting. The Board of Military Affairs noted that numerous game reserves had fallen into disuse and were overrun with dangerous animals. The government hoped that an open-reserve policy could eventually reduce forest cover and animal populations. ${ }^{38}$

In 1486, the Chosŏn government augmented the open-reserve policy with detailed regulations regarding the payment of bounties for tiger and leopard pelts. ${ }^{39}$ The bounty system was part of the government's broader institutionalization of tiger and leopard hunting in the late fifteenth through the sixteenth centuries. Local residents, not the king and his soldiers, were to hunt down and kill the dangerous beasts that lurked in their vicinity. The government recognized two grades of tiger and leopard hunting: official hunts and traps (konghamgi 公檻機) led by officials, and private hunts and traps (sahamgi 私檻機) organized by elites or villagers. If households involved in official hunts caught a large or

\footnotetext{
${ }^{36}$ Sim Sŭnggu, Im Changhyŏk, Chŏng Yŏnhak, Cho T'aesŏp, Sanyang ŭro pon sam kwa munhwa [An examination of daily life and culture through hunting]. (Seoul: Kuksa p'yŏnch'an wiwŏnhoe, 2011), 170; Kim Tongjin, Chosŏn chŏn'gi p'oho chŏngch'aek yŏn'gu: nongji kaegan üi kwanjŏm esŏ [A study of tiger hunting policy in the early Chosŏn era from the perspective of land reclamation] (Seoul: Sŏnin, 1998), 366. The largest recorded royal hunt in 1475 involved 28,155 troops.

${ }^{37}$ Sim Sŭnggu "Chosŏn sidae sanyang ŭi ch'ui wa t'ŭksŏng: kangmu wa hoekp'o rŭl chungsim ŭro" [The trends and characteristics of hunting in the Chosŏn dynasty: from the perspective of game reserves and tiger hunting], Yŏksa minsokhak 24 (2007): 173-175.

${ }^{38}$ Sŏngjong sillok 134 [1481/10/03].

${ }^{39}$ Issued by the Board of Military Affairs as the “Tiger Hunting Regulations” (p'oho chŏlmok 捕虎節目) and recorded in Sŏngjong sillok 198 [1486/12/2].
} 
medium tiger, they could choose from an array of rewards: three bolts of silk, twenty credited days of labor or office service, or one year of tax relief. Those who caught four tigers could be promoted into an official rank (kagye 加階). A small tiger or leopard of any size merited a smaller reward: two bolts of silk, ten credited work days, or six months of tax relief. ${ }^{40}$

The bounty system also reflected a broader shift in the tax structure. At the beginning of the dynasty, every district across the peninsula had to procure certain tribute items, including animal pelts, skins, feathers, horsehair, deer tongues for the king's dinner table, and horns for medicine. Local magistrates oversaw the collection of tribute items and their distribution to Seoul. However, by the early sixteenth century, the tribute system was already in disarray. Villagers and local officials alike often had trouble procuring the necessary items for the tribute levy. As a solution, they would use rice or cloth to purchase the necessary products from middlemen in a process called pangnap 防納 and taenap 代納. ${ }^{41}$ A variety of tribute merchants, warehouse masters, and bureau clerks supplied the government with necessary goods while making profits for themselves. In some cases, local elites such as Mukchae would engage in this pre-industrial brokerage.

When pelts and fur levies fell short, the burden fell on local magistrates and military garrisons to acquire furs demanded by the Chosŏn court. ${ }^{42}$ One solution was to send soldiers

\footnotetext{
${ }^{40}$ Sŏngjong sillok 198 [1486/12/02]. Private hunts garnered slightly smaller rewards. Designated leaders of hunting groups automatically received three years of tax relief for large and medium tigers and one year of tax relief for small tigers and leopards. For the rest of the group, large and medium tigers tendered a choice of two bolts of silk, twenty credited working days, or one year of tax relief. Small tigers and leopards earned a choice between one bolt of silk, ten credited working days, or six months of tax relief.

${ }^{41}$ The turn toward substitute payments at the local level presaged a more comprehensive reform of the taxation system in the seventeenth century, the Uniform Tax Law (Taedongpŏp 大同法). Kim Tŏkchin "16-17 segi ŭi sadaedong e taehan ilkoch'al" [An examination of private taedong in the $16^{\text {th }}$ and $17^{\text {th }}$ centuries], Chonnnam sahak 10 (1996); Yi Chŏngch'ŏl, "Chosŏn sidae kongmul punjŏng pyŏnhwa wa taedong ŭi onnŭi” [The distribution of tribute in the Chosŏn era and the meaning of taedong], Hanguksa hakpo 34 (2009); Palais, Confucian Statecraft and Korean Institutions, 771-780.

${ }^{42}$ Kim Tongjin, "16 segi samnam ŭi p'ohop'i cheyŏk kwa pangnap ŭi wisang: Mukchae ilgi rŭl chungsim ŭro" [The status of exemption payments in tiger and leopard furs and tribute contracting in the southern provinces during the sixteenth century: with focus on the Mukchae ilgi], Chibangsa wa chibang munhwa 16, no. 2 (2013): 132 .
} 
to hunt down tigers and leopards. The expenditure of men and time on hunting, though, was inordinately large. Magistrates preferred pressing local villagers to hunt and trap large felines. Brokers such as Mukchae would assist by facilitating necessary exchanges. If villagers happened to catch a tiger or leopard in a trap, they would sell its fur and other valuable parts to Mukchae for rice or cloth, which the villagers would then use to fulfill other tax obligations. Mukchae would further augment his fur supplies by sending slaves and hired hands to hunt big cats in the hilly countryside around Koesan and Sŏngju. His agents then sold the furs to local officials for a tidy profit. ${ }^{43}$

Such behavior from a former official certainly belied the court's hostility toward tribute contracting. ${ }^{44}$ Yet, this was the reality on the ground. In lieu of better infrastructure and bureaucratic surveillance, middlemen such as Mukchae greased the wheels of distribution. As James Palais notes, by the end of the sixteenth century, "almost every segment" of Chosŏn society was involved in the tribute contracting system, including "the yangban who employed their agents and slaves to engage in the trade themselves." 45

The rising stratum of local elites also had free rein to exploit their nearby environments. Mukchae's slaves felled oaks to make cartwheels. ${ }^{46}$ From pines, they gathered not just branches and lumber but also pine resin (songjin 松津) to make varnishes, adhesives, and incense. ${ }^{47}$ Carpenters were ordered to make dining tables, wood mortars, doors, and even

\footnotetext{
${ }^{43}$ Mukchae could not arbitrarily acquire his position as local fur broker. In 1553 , he first had to attain the permission of the magistrate, an awkward request for someone who so recently had walked the exalted floors of the Chosŏn court. The magistrate dismissed Mukchae's first request with a couplet: "Poor prospects and seeking a living are the same breed." Mukchae ilgi 6:2, 640 (Seoul: Kuksa p'yŏnch'an wiwŏnhoe, 1998). Also quoted in Kim Tongjin, "16 segi samnam ŭi p'ohop'i," 132.

${ }^{44}$ For examples, see Palais, Confucian Statecraft and Korean Institutions, 70-75, 771-780.

${ }^{45}$ Palais, Confucian Statecraft and Korean Institutions, 74.

${ }^{46}$ Mukchae ilgi, 8:2, 222. 李舟來見, 使扶眞木欲造車輪, 則當圖云云 ... 李舟復來言, 伐眞木待輸云云.

${ }^{47}$ Mukchae ilgi 8:1, 13-14, 22, 26.
} 
cotton gins. ${ }^{48}$ Mukchae's slaves hunted animals and gathered firewood. ${ }^{49}$ Mukchae had trees planted around his ancestors' tombs (and fiercely protected them).

Mukchae could generally acquire wood without government interference. When he wanted to utilize wood-related labor however, he often required cooperation from - and sometimes generated conflict with-local government. Specifically, Mukchae constantly required the services of craftsmen (changin 匠人) to build and repair his estate and its paraphernalia, from furniture and tools to fences and coffins.

Monks provided one source of craft and construction labor. Mukchae's use of monks was based on the close relationship he cultivated with local monasteries, particularly Anbong Temple. Within his diary, there are over 600 instances of Mukchae requesting or receiving goods and services from Anbong. These services included the use of monastic forests and monk labor. In exchange, Mukchae used his influence with local officials to exempt the temple and its monks from various tax and labor levees. ${ }^{50} \mathrm{He}$ also used his influence to help monks with various difficulties, even tree-related crimes. When a monk from Yongyŏn Temple asked for Mukchae's assistance in prosecuting someone who had felled trees, presumably near the temple, Mukchae agreed to write to the magistrate. In exchange, the grateful monk gifted Mukchae with goose quills and straw sandals. ${ }^{51}$

Mukchae would also utilize state-employed craftsmen. According to the Great Code of Administration, 2,795 government craftsmen were spread among the Board of Works' twenty-nine agencies, with most of them employed in manufacturing military equipment as well as making everyday goods and decorative vessels for royalty and officials. There were

\footnotetext{
${ }^{48}$ Yi Chŏngsu, "Mukchae ilgi rŭl t'onghae pon chibang changin tŭl ŭi sam" [The lives of local craftsmen according to the Mukchae ilgi], Chiyŏk kwa yŏksa 18 (2006): 212.

${ }^{49}$ Elites even concealed fuelwood from the authorities. Mukchae ilgi 8:2, 258.

${ }^{50}$ Yi Chŏngsu, “Mukchae ilgi rul t’onghae pon,” 188.

${ }^{51}$ Mukchae ilgi 9:2, 419.
} 
also twenty-seven different types of out-resident craftsmen (oejangin 外匠人) who handled duties in the provinces. ${ }^{52}$ Sŏngju had thirty-seven government craftsmen specializing in nine categories: paper; mats; brass; bows; arrows; skinning; blacksmithing; lacquering; and of course, carpentry. ${ }^{53}$

Over thirty-two years of his diary, Mukchae recorded 323 instances of himself using government or private craft labor. About half of the craftsmen were government-affiliated and the other half either worked for themselves or another household. Mukchae paid for labor services 35 percent of the time, usually in rice. For instance, he paid private carpenters one mal (about 5.96 liters) of rice for their services. ${ }^{54}$ For two chairs, he paid one toe (about 0.596 liters) of rice to another carpenter. In 67 percent of the instances, payment was conducted via exchanges of favors between Mukchae and the relevant party. ${ }^{55}$ Local craftsmen who wanted to escape labor duties often came to Mukchae to ask for help. As labor duty was essentially a tax payment, it was unattractive, burdensome, and was at times resisted. ${ }^{56}$ In 1552 , a stateemployed carpenter gave Mukchae eight citrons and requested his help in attaining an extended break from government duties. ${ }^{57}$ In 1557, a blacksmith (such'ŏljang 水鐵匠) came to ask Mukchae for assistance in attaining an overseer position (ch'abi 差備). As a gift, the

\footnotetext{
${ }^{52}$ Kyŏngguk taejŏn $6.5 \mathrm{a}-38 \mathrm{~b}$.

${ }^{53}$ Ibid., 6.19b-26a.

${ }^{54}$ Mukchae ilgi 8:2, 222.

${ }^{55}$ Yi Chŏngsu, "Mukchae ilgi rul t'onghae pon,” 183-232.

${ }^{56}$ Mukchae reports a carpenter named Sŏkkyŏn fleeing and absconding his duties. Mukchae ilgi 6:1, 656.

${ }^{57}$ Mukchae ilgi 5:1, 540. Also cited in Yi Chŏngsu, "Mukchae ilgi rul t’onghae pon," 199.
} 
blacksmith gave Mukchae some wood charcoal. ${ }^{58}$ Fuel wood and charcoal were valued gifts, particularly those of highest quality. ${ }^{59}$

Mukchae's influence on local government was a valuable currency, but as with all currency, its value lay in its limitations. When a carpenter named Sŏngmun was conscripted for corvée service, Mukchae wrote a letter to the magistrate claiming that he needed Sŏngmun to do some repairs at Anbong Temple. ${ }^{60}$ A few days later, another carpenter named Yi Ŏn requested Mukchae's help in waiving corvee duties. Mukchae had to deny his request because he had just made a similar request on behalf of Sŏngun."

Mukchae's penchant for usurping state-employed craftsmen for private service generated resentment from at least one government official. In 1559, Mukchae requested to the local magistrate that a matmaker named Ch'oe Sŏngmun be given back his old position, presumably as an employed craftsman. The magistrate replied by sentencing Ch'oe Sŏngmun to forty lashes. Mukchae assumed that the magistrate was "insulting him for monopolizing government craftsmen." Following the incident, there was a two-year period in which Mukchae desisted from using (or at least recording the use of) any state-employed craftsmen. $^{62}$

In another arena of prodigious wood use, funerary rites, Mukchae faced the same aforementioned pattern. The acquisition of related labor, particularly to protect the gravesite, engendered cooperation with local government. The necessary wood, however, could be

\footnotetext{
${ }^{58}$ Mukchae ilgi 8:2, 247. Another person named Yi Ch'un'yang came to Mukchae in 1548 asking for help in registering some reclaimed land and in attaining a position as overseer of mat craftsmen (sǒkchang haengsu 席匠 行首); he presented Mukchae with a gift of alcohol. Yi Chŏngsu, "Mukchae ilgi rul t'onghae pon," 199.

${ }^{59}$ Mukchae ilgi 8:2, 385. Good carpentry wood (sugongmok 手功木) was another valued present; Mukchae bestows his friend Suil with some after dinner. Mukchae ilgi 9:2, 430.

${ }^{60}$ Mukchae ilgi 8:2, 269. 吕岩簡喻, 木手石文役官事見捉, 請除云, 師簡白二道前, 欲得石文繕安举寺,則勿捉付文字成送, 乃遺呂岩.

${ }^{61}$ Mukchae ilgi 8:2, 276. 李偃簡求告除木手官役事, 不能從, 前請石文事故也.

${ }^{62}$ Yi Chŏngsu, "Mukchae ilgi rul t’onghae pon,” 202.
} 
acquired from local sources. When a female slave's son died, Mukchae simply had a Paulownia tree (tongmok 桐木) felled to provide her with a coffin. ${ }^{63}$

In 1535, Mukchae had to bury his father, a resultant process required months of arduous preparation, particularly in wood-related products. For coffin construction, Mukchae acquired fifteen pieces of pine lumber and then called in carpenters. ${ }^{64}$ To seal the coffin, Mukchae sent slaves to acquire a large amount of pine resin. ${ }^{65}$ He then had to line the burial chamber with lime (sŏkhoe 石灰) in accordance with Zhu Xi's Household Rituals. ${ }^{66}$ As Milan Hetjmanek notes, by the mid-sixteenth century, such complex funerary rites had become commonplace among the yangban elite. ${ }^{67}$ The efforts were arduous and the expenses heavy, but altogether they demonstrated status and power, particularly economic power. Participants could not always expect state assistance in burial preparations. ${ }^{68}$ Protecting the tomb, however, was a different matter. In another instance, Mukchae wrote to the local assistant magistrate ( $p^{\prime}$ an'gwan 判官) asking him to prohibit locals from interring their dead and burning fields around the tomb of his patrilineal ancestor, Yi Chonyŏn (1269-1343). Because a prominent ancestor was intimately tied to one's social

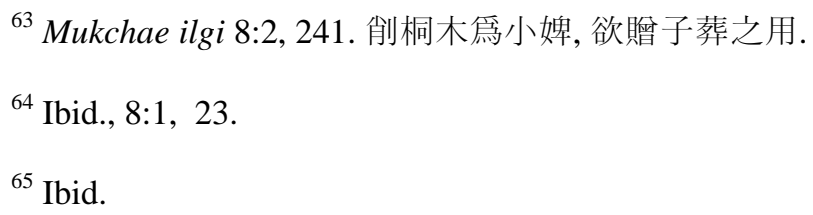
MA: Harvard University Asia Center, 2015), 203-204. Zhu Xi's Household Rituals prescribe lining graves with lime (sŏkhoe 石灰) and fine sand (sesa 細沙). Early Chosŏn preferences for lime foundations can be traced back to the dynasty's incipient decades. In 1420 for instance, King Sejong decreed, "Rather than stone, use limestone and fine sand for building foundations." Sejong sillok 9 [1420/09/04]. In the early years of the Chosŏn dynasty, the government corvéed 1,200 people from western Korea to bake limestone on Kanghwa island. T'aejo sillok 8 [1395/09/17]. The construction of Seoul's walls alone required over 9,610 slabs of limestone. Sejong sillok 15 $[1422 / 02 / 23]$.

${ }^{67}$ Milan Hetjmanek, "The Familiar Dead: The Creation of an Intimate Afterlife in Early Chosŏn Korea" in Death, Mourning, and the Afterlife in Korea: From Ancient to Contemporary Times, edited by Charlotte Horlyck and Michael J. Pettid (Honolulu: University of Hawai 'i Press: Center for Korean Studies, University of Hawai'i, 2014), 154-155.

\footnotetext{
${ }^{68}$ In special cases, the government could help with the transportation of coffins and lumber. Chosŏn officials, though, were mostly reluctant to set such precedents. Hetjmanek, "The Familiar Dead," 162.
} 
status in the Chosŏn era, protecting his tomb was a sacred task for any lineage heir. The magistrate accordingly sent clerks (sŏwŏn 書員) to help Mukchae drive away the intruders and even appointed a tomb guardian (myojik 墓直) to watch over the tomb. ${ }^{69}$ Mukchae also requested, multiple times, that the government prosecute people who had cut trees around his tombs. ${ }^{70}$ The coffin and burial chamber could be constructed without government help, but protecting the gravesite required ongoing government assistance.

Overall, while Miam and Mukchae both had privileged access to forests and forest resources, such privileges required significant engagement with the state. Gifts had to be exchanged; favors had to earned and repaid. The early Chosŏn state had built a socio-political infrastructure that required even the most powerful local elites to engage the government to acquire wood or wood-related labor. Moreover, as seen in the case of Mukchae's ancestral tomb, local elites could rely on the state to prosecute certain practices that threatened their economic interests. It is important to reiterate that such interactions benefited both the central government and local elites. During the Imjin War (1592-1598), local elites remained fiercely loyal to the dynasty. Some led guerilla bands known as "righteous armies" (üibyŏng 義兵) against the invading Japanese; others held consolidate larger regional militias and donated foodstuffs to the Chosŏn and Ming armies. ${ }^{71}$

\section{Status, School, Lineage: Local Organizations as Cultural and Intellectual Brokers}

After the tumult of the Imjin War and the factional battles of the early seventeenth century, a

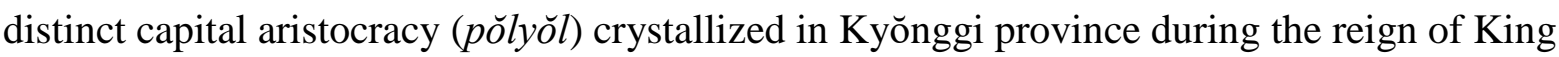

\footnotetext{
${ }^{69}$ Mukchae ilgi 9:2, 404.

${ }^{70}$ Mukchae ilgi 9:2, 390, 432.

${ }^{71}$ Martina Deuchler, Under the Ancestors' Eyes, 225; Kim Sŏngu, Chosŏn chunggi kukka wa sajok [The state and elites in the mid-Chosŏn era] (Seoul: Yŏksa pip'yŏngsa, 2001).
} 
Injo (1623-1649). Kyŏnggi residents dominated the top civil examination until the end of the dynasty. Through marriage, factional ties, and geographic proximity to special examinations, the capital aristocracy solidified around a relative handful of yangban families at the expense of what Ch'a Changsŏp refers to as the hanjok (寒族) — the localized yangban majority. ${ }^{72}$

However, local elites did not drift into obscurity; on the contrary, they forged new purposes that reshaped the Chosŏn state. The emergence of a distinct capital aristocracy was mirrored by an expanding set of provincial organizations fulfilling a growing array of functions. One was the hyangan, what Fujiya Kawashima refers to as "local gentry associations." Kawashima found that central bureaucrats dominated these associations until the mid-sixteenth century, when "increasingly yuhak and other title and degree holders without official employment replaced the bureaucrats as typical members. ${ }^{, 73}$ Yet, even as central official members diminished from hyangan registers during the seventeenth and eighteenth centuries, so-called yuhak members in the provinces continued to spread Confucian rituals and construct private academies (sŏwŏn) and shrines.

The rise of increasingly localized organizations might seem to reflect lost political influence. Yet, scholarly networks based around private academies diversified the realm of the "political" and reshaped the figuration of the state. As Hwisang Cho argues, while many local yangban may not have served the state through placement in the central bureaucracy, they still "claimed their role as legitimate political actors on a par with the state authority in terms of improving social ethics." ${ }^{, 74}$ This localization of the Confucian socio-political agenda

\footnotetext{
${ }^{72}$ Ch'a Changsŏp, Chosŏn hugi pŏryŏl yŏn'gu [A study of the pŏryŏl in the late Chosŏn dynasty] (Seoul: Ilchogak, 1997).

${ }^{73}$ Fujiya Kawashima, “A Study of the Hyangan: King Groups and Aristocratic Localism in the Seventeenth- and Eighteenth-Century Korean Countryside," The Journal of Korean Studies 5 (1984): 9.

${ }^{74}$ Hwisang Cho, "The Community of Letters: The T'oegye School and the Political Culture of Chosŏn Korea, 1545-1800." Ph.D. dissertation, Columbia University (2010), 338.
} 
began in the sixteenth century with the ideas of T'oegye Yi Hwang and solidified particularly in the southeast region as local yangban there utilized private academy networks, petitions, and what Cho calls "textual domination" to thrust local voices into central bureaucratic affairs. ${ }^{75}$ The central government, in turn, recognized the authority of the local scholarly networks, thus empowering their socio-political discourses and in turn forcing us to recognize that "state Confucianism" in the late Chosŏn era was a by-product of center-local interactions and post-1500 local developments.

Local organizational proliferation further cemented common cultural ties across the country and between center and local. The seventeenth and eighteenth centuries saw the continuous rise of patrilineal lineage associations (munjunggye) throughout the countryside, contributing to what Martina Deuchler calls the "Confucian transformation of Korea." Choe Sŭngmo has argued that a growing number of local yangban used lineage associations to spread and regulate common Confucian rituals, with older popular practices denounced as “dishonorable rituals” ( $\breve{m} s a$ 淫祀). ${ }^{76}$ Both central and local interests gradually coalesced around cultural practices such as the ancestral cult and similarly structured kinship groups that regulated collective properties and inheritance matters. ${ }^{77}$ Organizations built around status, scholarship, kinship, and ritual produced the institutional mechanisms for imposing power, norms, and values. They produced, in Bourdieu's words, “the performative discourse on the state which, under the guise of saying what the state is, caused the state to come into being by stating what it should be.",78

\footnotetext{
${ }^{75}$ Ibid., 339.

${ }^{76}$ Chŏng Sŭngmo Chosŏn hugi chiyŏk sahŏe kujo yŏn'gu [A study of the regional social structure in the late Chosŏn era] (Seoul: Minsok’wŏn, 2010), 63-69.

${ }^{77}$ Martina Deuchler, The Confucian Transformation of Korea: A Study of Society and Ideology (Cambridge, MA: Harvard University Press, 1992), 287-289.

${ }^{78}$ Bourdieu, Wacquant, and Farage, "Rethinking the State," 16.
} 


\section{Administrative Brokers: Clerks, Soldiers, and Monks}

The local elements of bureaucratic government, notably clerks (hyangni and ajŏn) and local military officials, also expanded during the seventeenth and eighteenth centuries. Local functionaries are often depicted as the bogeymen of Chosŏn society; they were the unenviable middle men, castigated by the elite as immoral and self-serving and resented by the commoners as tax collectors and extortionists. Yet, these were the very people who made the wheels of Chosŏn society turn; they collected the taxes, implemented the policies, handled the lawsuits, manned the infrastructure, and accomplished the daily tasks that bridged the gap between central government and local realities. ${ }^{79}$

Starting in the mid-sixteenth century, according to Kwŏn Kijung, local hyangni functions began diversifying in line with the growing populations and complexities of local society. Magistrates, in particular, could utilize clerks as a check against the power of local yangban. ${ }^{80}$ During the Imjin War, hyangni gained even more importance as their expertise became critical for transporting war material and facilitating wartime governance; their skills were even utilized by Hideyoshi's troops in occupied areas. ${ }^{81}$ In the aftermath of the war, new tax systems meant to rebuild Chosŏn finances further empowered the clerk stratum. Chang Tongp'yo and Kim Tŏkchin have both argued that expansion of local officials in the seventeenth and eighteenth centuries can be correlated with the introduction of the miscellaneous tax payments (chabyŏkse 雜役稅) that local communities would pay as a

\footnotetext{
${ }^{79}$ Bradley Reed has addressed the preponderance of gentry-centered studies in Chinese historiography by producing a detailed work on country clerks and runners in Qing China. Reed, Talons and Teeth: County Clerks and Runners in the Qing Dynasty (Stanford, CA: Stanford University Press, 2000).

${ }^{80}$ Kwŏn Kijung, Chosŏn hugi hyangni wa chibang sahoe [Hyangni and local society in the late Chosŏn era] (Seoul: Kyŏngin, 2011), 202.

81 Ibid., 203-206.
} 
unit. $^{82}$ By 1800 , the hyangni comprised a diverse array of local officials tied by marriage, specialization, and multiple generations of service in their locality. ${ }^{83}$

Similarly, the function of Chosŏn granaries (sach'ang) underwent a key shift during this period. Whereas early Chosŏn granaries had mainly served as a source of famine relief, seventeenth and eighteenth-century granaries served as sources of local finance. Local officials would lend out grain and fund themselves through interest and surcharges. By the end of the eighteenth century, every district in Korea relied on some form of the grain loan system to fund local government affairs and official livelihoods. While such a localized system was less draining on the central treasury, it also rendered administration subject to an array of middlemen. ${ }^{84}$

The functions of the military during the late Chosŏn era also shifted, especially in the realm of finance. The Imjin War and the Manchu incursions of 1627 and 1636 had devastated the economy and left agriculture in need of reconstruction. Rather than rebuilding the countryside with funds from the depleted central treasury, the government allowed certain agencies, including the military, to appropriate more lands and directly collect revenues.

For instance, in the middle of the seventeenth century, reformist minister Kim Yuk (1580-1658) championed military farms (tunjŏn 屯田) as a cost-effective form of military finance that could also alleviate social and environmental problems plaguing the countryside. Kim Yuk had made his name as the architect of the Uniform Tax Law (taedongpŏp 大同法) that streamlined methods of tax payment in seventeenth-century Korea. Late in his illustrious

\footnotetext{
${ }^{82}$ Chang Tongp'yo, Chosŏn hugi chibang chaejŏng yŏn'gu [A study of regional finance in the late Chosŏn era] (Seoul: Kukhak charyowŏn , 1999); Kim Tŏkchin, Chosŏn hugi chibang chaejŏng kwa chapyŏkse [Regional finance and the miscellaneous tax in the late Chosŏn era] (Seoul: Kukhak charyowŏn, 1999).

${ }^{83}$ Kwŏn Kijung, Chosŏn hugi hyangni, 94-99, 208.

${ }^{84}$ Mun Yongsik, “17-18 segi sach'ang ŭl t’onghan chibanggwan ŭi chaejŏng poyong sarye [Case studies in local government efforts to replenish finances through granaries in the $17^{\text {th }}$ and $18^{\text {th }}$ centuries]," Yŏksa wa hyŏnsil 72 (2006): 70-101; Son Pyŏnggyu, Chosŏn wangjo chaejŏng sisŭt'em ŭi chaepalgyŏn [Rediscovering the fiscal system of the Chosŏn dynasty] (Seoul: Yŏksa pip'yŏngsa, 2008), 315-392.
} 
career, in 1653, he heard reports of a disturbing trend: in western Kangwŏn province, peasants were fleeing their villages to avoid military service and tax payments. Worried, Kim submitted a memorial to the king describing the situation:

These vagrants (yumin 流民) are solely cultivating mountain lands as their livelihood and roaming around like birds and beasts ... The fields are abandoned, and famous mountains day by day are stripped away. Needless to say, these are serious concerns. ${ }^{85}$

Kim proposed that the government establish, on suitable “empty areas” (konghan 空閉), agricultural garrisons to be governed by special military commanders (pyŏlchang 別將) and allotted between ten and one hundred vagrants each. A three-year tax break to the vagrants was offered as an enticing lure; in exchange, these vagrants-turned-garrison tenants (tunmin 屯民) were prohibited from cultivating mountain areas. The end result, argued Kim, would be "upright hearts and minds for the people" and the "benefits of conservation for the state." $\$ 86$

Kim's proposal reflected a growing trend. The mid-to-late seventeenth century would witness the significant expansion of the Chosŏn state's administrative capacities throughout the countryside. The problem of vagrancy, in particular, became a common justification for the establishment of new military farms and protected forests, particularly in the western parts of mountainous Kangwŏn province and the coastal areas of Ch’ungch’ŏng and Chŏlla provinces. ${ }^{87}$ The sedentary bureaucrat's revulsion to vagrancy, a phenomenon well noted by

\footnotetext{
${ }^{85}$ Hyojong sillok 11 [1653/08/11].

86 民有一定之心, 國有存保之惠矣. Hyojong sillok 11 [1653/08/11].

${ }^{87}$ Song Yangsŏp, “17 segi kunyŏngmun tunjŏn ŭi hwaktae wa kyŏngyŏng hyŏngt'ae ŭi pyŏn’hwa” [A study in the enlargement and changes in management of military-managed tunjŏn during the $17^{\text {th }}$ century], Yŏksa wa hyŏnsil 36 (2000); Pyŏn Chusŭng “Chosŏn hugi yumin chŏngch'aek yŏn'gu” [A study of vagrancy policy in the late Chosŏn dynasty],_Minjok munhwa yŏn'gu 34 (2001): 59.
} 
anthropologists, compounded seventeenth-century Korean concerns over environmental degradation and fiscal health. ${ }^{88}$

As the seventeenth century wore on, the government continued to implement stricter measures aimed at controlling populations and the countryside. In 1675, an official named Yun Hyu (1617-1680) proposed the reintroduction of the Five Household Control Law. ${ }^{89}$ The law, based on examples from the Rites of Zhou, had been discussed in the court during the fifteenth century, but widespread implementation was never undertaken. ${ }^{90}$ Now, in the postwar environment of the seventeenth century, Yun cited the ongoing vagrancy problem as a major impetus for reintroducing the Five Household Control system.

Yun proposed that every settlement be organized into a basic unit of five households that in turn were subordinated to larger administrative villages ( $r i$ 里) and, on the next level up, townships (myŏn 面). The law exhorted the five-household units to assist their members in key rituals such as weddings and funerals and to ensure the fulfillment of tax payments and corvée service. Household units were also to maintain irrigation works and grain storage facilities. Furthermore, the regulations prevented most people from moving into any unregistered or unverified locality. Uncooperative village leaders were threatened with deportation. $^{91}$

\footnotetext{
${ }^{88}$ For examples of James Scott's arguments, see Seeing like a State: How Certain Schemes to Improve the Human Condition have Failed (New Haven, CT: Yale University Press, 1999). For examples of late Chosŏn concerns over vagrancy as related to deforestation, see Yi Uyŏn. Hanguk ǔi sallim soyujedo wa chŏngch'aek ǔi yŏksa, 1600-1987 (Seoul: Ilchogak, 2007), 60-162.

${ }^{89}$ For original text, see Pibyŏnsa tŭngnok [Records of the Border Defense Command] Sukchong 1/5/9 [1675]. For further analysis, see Chŏng Chinyŏng, Chosŏn sidae hyangch'on sahoesa [A social history of rural communities in the Chosŏn dynasty] (Seoul: Han'gilsa, 1998), 267-271; Deuchler, Under the Ancestors' Eyes, 261-262. For links between the Five Household Control Law and the broader vagrancy problem, see Pyŏn Chusŭng, "Chosŏn hugi yumin," 53-55.

${ }^{90}$ The 1468 forest controls around Seoul included usage of the Five Household Control Law, but there is no evidence of actual implementation.

${ }^{91}$ Sukchong sillok 4 [1675/9/26]; Chŏng Chinyŏng, Chosŏn sidae hyangch'on sahoesa [A social history of rural communities in the Chosŏn dynasty] (Seoul: Han'gilsa, 1998), 267-271.
} 
Due to the infrastructural and technological limits of the pre-industrial Chosŏn polity, the Five Household Control Law was unevenly implemented in the late Chosŏn era. As with the state forestry system, the government had trouble recruiting lower-level administrative personnel. Evasion and irregularities were also rampant, largely due to the machinations of local elites.

Yet, seen in long-term perspective, the Five Household Control Law was part of a significant expansion of administrative control over daily life in the Chosŏn dynasty. The suppression of vagrancy, the recovery of revenue, and the reorganization of villages into legible units all followed a determined post-Imjin effort to re-establish order in the countryside. Early Chosŏn officials had batted around similar proposals, but they only reached wider implementation after the depredations of the Imjin War and Manchu invasions. Likewise in other spheres, particularly forestry, the postwar Chosŏn government laid the groundwork for a more legible administrative landscape to be implemented by a growing array of lower-level agents and middlemen.

\section{Brokering the Protected Forests}

Forests during the seventeenth and eighteenth centuries were increasingly managed through a series of brokers: wardens (sanjik 山直) corvéed from localities, stewards (kamgwan 監官) appointed by the local yangban association, and military and civil officials to oversee the protection process. New edicts, moreover, cracked down on local elite collusion with forest manager. Various social institutions ranging from Buddhist monasteries to village kye 契 were incorporated into the infrastructure of the Chosŏn state.

In 1684, the Border Defense Command (Pibyŏnsa) produced a set of statutes titled “Pine Prohibition Regulations” (songgŭm samok 松禁事目) that revised and strengthened 
government-controlled Reserved Forests (pongsan 封山). ${ }^{92}$ Official jurisdictions and the Reserved Forest selection process were clearly delineated, investigative procedures were meticulously ordered, and the punishments of corrupt forestry officials were described in detail. ${ }^{93}$ In the statute preface, the authors noted that "the coasts are limitless in the people's distress, while the prohibitions fall apart day by day." The preface went on to attest that “these corruptions ( $p$ 'ye 弊) originate in the navy commanders' inability to enforce and the magistrate's inability to act" while forests wardens and stewards were "too many in number" and hence were "pestering the people." Accordingly, the regulations regulated the number of wardens per forest, while stewards were to be selected from the local yangban association. ${ }^{94}$

The government's complaint about wardens and stewards being "too many in number" and "pestering the people" reflected the more prominent role for a variety of lower-level officials in seventeenth-century Chosŏn. During the eighteenth century, the central government tried to rectify problems related to official corruption by sending more inspectors (ŏsa 御使) to surveil local governments. ${ }^{95} \mathrm{New}$ regulations dictated strict punishments for officials who illegally seized goods (changni 䁍吏) or turned blind eyes to wrongdoers (pulgak sirinyul 不覺失因律, literally the "law regarding failing to reveal escaped prisoners).

Villages also underwent significant changes in internal organization. In the late Chosŏn era, Koreans of all status groups increasingly formed themselves into mutual aid

\footnotetext{
92 "Reserved Forest" was the government's preferred designation for the old Restricted Forests after 1600.

${ }^{93}$ Pibyŏnsa tŭngnok, Sukchong 10/02/30 [1684].

94 Ibid.

${ }^{95}$ For more information on government attempts to control magistrates and other local officials in the eighteenth century, see Han Sanggwŏn, "Ǒsa p'agyŏn kwa chibang chibae kanghwa” [The dispatch of inspectors and the strengthening of regional control], in Han'guk yŏksa yŏn'guhoe, ed., Chosŏn ün chibang ŭl ottok'e chibae haennŭn'ga? (Seoul: Acanet, 2000), 205-219.
} 
organizations known as kye. Kye purposes ranged from granary and forest management to supporting funerary rituals and collecting taxes, and their proliferation generally coincides with the localization trend seen in the spheres of yangban, clerks, and the military. Social and institutional relationships within kye were quite varied; Pak Chongch'ae has found that Pine Associations (songgye 松契) meant to protect local forests could be exclusive to certain status groups, mixed across status lines, or even run by local officials. ${ }^{96}$

One Pine Association charter, from Hadong district in southeastern Korea and dated 1860, starts with the following quote: "In the governance of the state, there is nothing more important than the protection of pines." 97 Whether the villagers actually believed this is doubtful; the line quotes a 1788 iteration of the government's Pine Protection Regulations. Still, the Pine Association document does reflect how central policies could become enmeshed in local organizations. Each village in the district was to appoint one warden and one steward, and furthermore, each village was to implement the Five Household Control Law to ensure that their neighbors did not cut down any pines. If any villagers were caught, the headman of the perpetrator's five-household group would be punished as well.

\section{Concluding Remarks}

Sometime around the year 1800, near the picturesque hamlet of Kangjin in southwestern Korea, an exiled official named Chŏng Yagyong (1762-1816) came across a most disturbing sight. A monk was methodically killing pine seedlings across a hillside. Thousands of seedlings, most barely a few inches tall, were being removed to their roots and then discarded.

\footnotetext{
${ }^{96}$ Pak Chongch'ae, "Chosŏn hugi kŭmsonggye ǔi yuhyŏng” [Types of Pine Prohibition Associations in the late Chosŏn], Sup kwa munhwa ch'ongsŏ 8 (2000): 192

97 “Songgye chŏlmok” [Pine Association regulations], Kyujanggak no. 12329 (1860).
} 
When Chŏng inquired about the commotion, to his surprise, the monk burst into tears. Once recovered, he told his story. ${ }^{98}$

The surrounding forest was actually a state-managed reserve for supplying navalgrade pine timber, and some years earlier, the provincial navy headquarters had charged the monk's monastery with managing the woods. The monks took the job seriously, patrolling the forest night and day, according to the monk, even eating cold rice "to save on firewood." They succeeded to the point that "the woodcutters of the town did not dare to approach the mountain." Yet, the monks' labor would be in vain. One day, a military officer from the provincial navy headquarters arrived to inspect the monks' efforts. He angrily pointed at a few felled pine trees, victims of an earlier storm, and then violently punched a monk in the chest. Though the monks beseeched that they were innocent of any wrongdoing, the officer had no sympathy, and the monks were forced to pay a substantial restitution. The traumatic ordeal triggered a new realization at the monastery. Pine protection was a disastrous burden, not a duty. Minimizing forest growth could minimize chances of punishment.

Tasan saw the monks' plight as an indictment of the late Chosŏn administrative system, a declining order that, in his eyes, was overrun with avaricious officials. Yet, Tasan and other later Chosŏn commentators may not have fully realized the long-term course of Chosŏn's brokered state. From the sixteenth century onward, the central government had maintained an amazing level of stability by co-opting various local powerholders and lowerlevel officials as the state's cultural, administrative, and economic brokers. Brokerage helped the dynasty propel both a legitimating cultural vehicle in the form of Confucianism and a systemizing institutional vehicle in the form of the bureaucracy's local arms - the clerks, military, wardens, and stewards. Cooperation with local elites helped the dynasty survive late

\footnotetext{
${ }^{98}$ This anecdote is from Chŏng Yagyong's poem "Sŭng palsong haeng" [Monk pulling out pine trees] published in his Mongmin simsŏ [Admonitions for Governing the People], 5:1, "Kongjŏn" [Section on public works]. Chŏng Yagyong, Mongmin simsŏ [Essays from the heart on governing the people], Tasan yon'guhoe, ed. (Seoul: Ch'angbi, 2000).
} 
sixteenth and early seventeenth-century cataclysms that overturned Korea's neighbors. Incorporation of local bureaucratic elements allowed the dynasty to recover and prosper in the seventeenth and eighteenth centuries.

Bruce Cumings begins his seminal work, The Origins of the Korean War, by noting that a Korean from the fifteenth century "strolling the streets of Seoul in 1875 " would find very little that would startle him. ${ }^{99}$ I attest that if a fifteenth-century Korean had embarked on a countrywide tour in 1800 , the contrasts between the centuries would have been eye-opening. The visitor would have seen vibrant academies in the southeast spouting politics and philosophy; well-organized lineages nestled in remote corners like Haenam and Yean; a host of clerks, soldiers, and middlemen brokering wide varieties of resources; and a robust array of local organizations configuring intellectual culture and workaday life.

But what made the Chosŏn system work did not necessarily apply after 1800 . While the brokered state was effective in maintaining domestic stability, its institutions could not quell rising social and economic inequities. Corruption in the taxation, granary, and forestry systems plagued their efficacy and contributed to local resentments leading to major rebellions in 1812,1862 , and 1894 . And when series of centralizing attempts emerged from the 1860 s onward, the central government would find it difficult to disengage the state from its brokers.

\footnotetext{
${ }^{99}$ Bruce Cumings. Origins of the Korean War, vol. 1: Liberation and the Emergence of Separate Regimes, 1945-1947 (Studies of the East Asian Institute, Columbia University Press, 1981), 3.
} 